\title{
Analisis Kualitas Website Menggunakan Metode Webqual Pada Malang Dorm Hostel
}

\author{
Fachri Ayudi Fitrony ${ }^{1}$, Fitri Marisa ${ }^{2}$ \\ ${ }^{1}$ Fafaosd24@gmail.com, ${ }^{2}$ fitrimarisa@widyagama.ac.id
}

Program Studi Teknik Informatika, Universitas Widyagama Malang

\begin{abstract}
Technological advances have had impact on all aspects of human life, one of which is in the business world as well as the internet. This study aims to analyze the quality of websites in malang dorm hostels based on WEBQUAL method with dimensions Usability, Information, and Service Interaction. the gap or gap values of all three dimensions of WEBQUAL. The results obtained from this study as a whole, the value of the difference between the actual quality (performance) and the quality of the ideal (importance) has a negative value. total average gap or gap of - (0.84). The largest gap value is in the information dimension with gap or gap value of - (1.33). Based on it can be concluded that the website of Malang Dorm Hostel is actually felt not meet the ideal quality, especially related to information and services contained on the website. Indicators that need attention include information with the right level of detail, other than that reliable information attributes, security in transactions, accurate information, personal information security, information in the appropriate format, actual information, relevant information and easy navigation. It is expected that this research can help website management of Malang Dorm Hostel in improving the quality of their service in face of competition and answer the need and expectation of society.
\end{abstract}

Intisari - Kemajuan teknologi telah berdampak pada seluruh aspek kehidupan manusia, salah satunya adalah pada dunia bisnis begitu pula bersamaan dengan adanya internet. Penelitian ini bertujuan untuk menganalisis kualitas website di malang dorm hostel berdasarkan metode WEBQUAL dengan dimensi Usability, Information, dan Service Interaction. nilai kesenjangan atau gap dari ketiga dimensi WEBQUAL. Hasil yang didapatkan dari penelitian ini secara keseluruhan, nilai selisih antara kualitas aktual (performance) dan kualitas ideal (importance) memiliki nilai negatif. total rata-rata kesenjangan atau gap sebesar $-(0.84)$. Nilai kesenjangan terbesar terdapat pada dimensi information dengan nilai kesenjangan atau gap sebesar -(1.33). Berdasarkan hal tersebut dapat disimpulkan bahwa website Malang Dorm Hostel secara aktual dirasakan belum memenuhi kualitas ideal terutama yang berhubungan dengan informasi dan layanan yang terdapat pada website. Indikator yang perlu mendapat perhatian antara lain adalah informasi dengan tingkat detail yang tepat, selain itu atribut informasi dapat dipercaya, keamanan dalam bertransaksi, informasi akurat, keamanan informasi pribadi, informasi dalam format yang sesuai , informasi aktual, informasi relevan dan mudah melakukan navigasi. Diharapkan penelitian ini dapat membantu manajemen website Malang Dorm Hostel dalam meningkatkan kualitas layanan mereka dalam menghadapi persaingan dan menjawab kebutuhan dan harapan masyarakat.

Kata Kunci- Importance Performance Analysis, Malang Dorm Hostel, Kualitas, Website, WEBQUAL.

\section{PENDAHULUAN}

Teknologi informasi merupakan bagian dari kehidupan manusia saat ini[1]. Penelitian ini mencoba untuk melakukan pengukuran terhadap kualitas website[2] Malang Dorm Hostel dan bisa dijadikan acuan untuk meningkatkan pengelolaan website menjadi lebih baik lagi. Pendekatan dimensi Webqual yaitu usability[3], information quality[4], dan service interaction[5] yang dinilai berdasarkan perspektif tingkat kinerja(performance)dan tingkat kepentingan (importance). Responden yang diteliti dalam penelitian ini berjumlah 100 pengguna dengan menggunakan teknik sampling incidental. Tingkat kualitas dapat ditunjukan dengan menghitung nilai kesenjangan (gap) antara dua perspektif tersebut.

Selain itu, hasil dari nilai kesenjangan atau gap dari ketiga dimensi WEBQUAL[6]. Hasil yang didapatkan dari penelitian ini secara keseluruhan, nilai selisih antara kualitas aktual (performance)[7]dan kualitas ideal (importance)[8] memiliki nilai negatif. Total rata-rata kesenjangan atau gap sebesar (0.84). Nilai kesenjangan terbesar terdapat pada dimensi information dengan nilai kesenjangan atau gap sebesar (1.33). Berdasarkan analisis yang dilakukan terhadap penilaian atribut kualitas website Malang Dorm Hostel[9]yang kemudian dapat menjadi feedback atau umpan balik bagi perusahaan sebagai indikator dalam menentukan kualitas mana saja yang telah sesuai dengan keinginan pengguna dan mana saja yang membutuhkan perbaikan bagi kemajuan website perusahaan dimasa yang akan datang. 


\section{KAJIAN PUSTAKA}

\section{A. Website Malang Dorm Hostel}

Situs Web Malang Dorm Hostel di Kota Malang memiliki berbagai fitur yang di tawarkan contohnya informasi tentang penginapan Harga, Kualitas, Fasilitas serta promo Tour ke tempat bagus untuk di kunjungi para Backpacker dari Indonesia ataupun dari turis dari luar negeri. Jumlah Kunjungan Wisatawan ke Malang Dorm Hostel [9].

Tabel 1.

Jumlah Pengunjung Yang Menginap Di Malang Dorm Hostel Tahun 2014-2016

\begin{tabular}{|l|c|c|c|}
\hline \multicolumn{1}{|c|}{ Bulan } & Tahun 2014 & Tahun 2015 & Tahun 2016 \\
\hline Januari & 417 & 413 & 410 \\
\hline Februari & 419 & 398 & 421 \\
\hline Maret & 420 & 376 & 395 \\
\hline April & 417 & 419 & 390 \\
\hline Mei & 426 & 423 & 413 \\
\hline Juni & 490 & 369 & 428 \\
\hline Juli & 433 & 350 & 433 \\
\hline Agustus & 431 & 441 & 388 \\
\hline September & 428 & 401 & 401 \\
\hline Oktober & 380 & 399 & 370 \\
\hline November & 410 & 345 & 368 \\
\hline Desember & 411 & 422 & 339 \\
\hline Jumlah & 5.082 & 4.755 & 4.756 \\
\hline
\end{tabular}

Sumber : Malang Dorm Hostel, 2017

Tabel 2.

Jenis dan Jumlah Keluhan Pelanggan di Malang Dorm Hostel Tahun 2016

\begin{tabular}{|l|l|l|}
\hline No & $\begin{array}{l}\text { Jenis Keluhan } \\
\text { Pelanggan }\end{array}$ & $\begin{array}{l}\text { Jumlah Keluhan } \\
\text { (Orang) }\end{array}$ \\
\hline 1 & Kebersihan kamar hostel & 3 \\
\hline 2 & Kerapian karyawan & 5 \\
\hline 3 & $\begin{array}{l}\text { Kecepatan dalam } \\
\text { pelayanan }\end{array}$ & 2 \\
\hline 4 & Keterampilan dalam tugas & 3 \\
\hline 5 & Pelayanan sopan & 5 \\
\hline
\end{tabular}

\section{B. Webqual}

Webqual telah mengalami beberapa iterasi dalam penyusunan kategori dan butir-butir pertanyaannya. Versi terbaru adalah Webqual 4.0 yang menggunakan tiga kategori pengukuran dengan 22 butir pertanyaan. Webqual4.0 disusun berdasarkan tiga area utama yaitu kualitas informasi, kualitas interaksi dan usability [3],[4],[5] didefinisikan sebagai berikut:

1. Kualitas informasi

2. Kualitas interaksi

3. Kualitas usability

\section{Importance Performance analysis (IPA)}

IPA (Importance performance analysis) diperkenalkan oleh Martilla dan James dan terdokumentasi dengan baik serta telah mampu menunjukkan kemampuan untuk menyediakan manajerial pelayanan dengan informasi yang berharga untuk pengukuran kepuasan keduanya dan alokasi sumber daya yang efisien di dalam format yang sesuai dengan mudah.

\section{Website}

Pengunjung menilai kinerja sebuah situs pada kemudahan dalam menggunakan dan daya tariknya. Kemudahan dalam menggunakan memiliki maksud situsnya dapat diunduh secara cepat, halaman pertama mudah dimengerti, dan mudah untuk berpindah ke halaman lain dengan cepat. Daya tarik dapat dipastikan ketika setiap halaman bersih dan tidak dipenuhi dengan isi, penataan huruf dan ukurannya dapat dengan mudah dibaca, dan situsnya menggunakan warna dan suara yang cukup atau tidak berlebihanApp Inventor

\section{METODE PENELITIAN}

\section{A. Metode Penelitian}

Penelitian yang dilakukan dimasukkan ke dalam kategori penelitian deskriptif kuantitatif. Variabel-variabel yang digunakan pada penelitian ini adalah berdasarkan pada metode WEBQUAL versi 4.0 berdasarkan penelitian yang dilakukan oleh Barnes dan Vidgen yang terdiri dari usability, information, dan service interaction dimana terdiri dari 22 total indikator yang dapat dibedakan menjadi dua jenis, yaitu kualitas yang saat ini dirasakan atau aktual terjadi yang disebut dengan (Performance) dan kualitas yang diharapkan dan dianggap penting untuk dikembangkan yang disebut dengan (Importance). Variabel penilaian yang menjadi indikator pada penelitian ini dapat dilihat pada Tabel 3 dibawah ini adalah tabel dimana belum dilakukan uji validitas dan realibilitas dalam penentuan penilaian yang digunakan pada penelitian ini. 
Tabel 3.

Variabel penilaian indicator

penelitian

\begin{tabular}{|c|c|c|}
\hline Kategori & Imdicator & $\begin{array}{l}\text { Kode } \\
\text { variabel }\end{array}$ \\
\hline \multirow[t]{8}{*}{ Urability } & $\begin{array}{l}\text { Interaksi jelas dan tepat di } \\
\text { mengerti }\end{array}$ & USAI \\
\hline & Mudah melakukam navigasi & USA2 \\
\hline & Tampilan merank & USA3 \\
\hline & Desain Sesuai & USA4 \\
\hline & Daya saing & USAS \\
\hline & $\begin{array}{l}\text { Mudah dipelajari dan } \\
\text { dioperasikan }\end{array}$ & USA6 \\
\hline & Mudah digunakan & USAT \\
\hline & Pengalaman positif & USAB \\
\hline \multirow[t]{7}{*}{ Tybormation } & Informasi alcurat & INEI \\
\hline & Informasi dapat dipercaya & INIF2 \\
\hline & Informasi alctual & INIF3 \\
\hline & Informasi relevan & INIF4 \\
\hline & Informasi mudah dimengerti & INIFS \\
\hline & $\begin{array}{l}\text { Informasi dengan tinglicat detail } \\
\text { yang tepat }\end{array}$ & INE6 \\
\hline & $\begin{array}{l}\text { Informasi dalam format yang } \\
\text { sesuai }\end{array}$ & INE? \\
\hline \multirow{7}{*}{$\begin{array}{l}\text { Service } \\
\text { Dnteraction }\end{array}$} & Reputasi baik & SERVI \\
\hline & Reamanan dalam bertrangalcsi & SERT2 \\
\hline & Reamanan informasi pribadi & SERV3 \\
\hline & Ruang personalisasi & SERT4 \\
\hline & $\begin{array}{l}\text { Pelaksanaan layanan sesuai } \\
\text { janji }\end{array}$ & SERV5 \\
\hline & $\begin{array}{l}\text { Remudaham bericomunikasi } \\
\text { dengan perusahaan }\end{array}$ & SERT6 \\
\hline & Rasa komannitas & SERTV \\
\hline
\end{tabular}

Tabel 4.

Kriteria pemilihan sampel

\begin{tabular}{|c|l|}
\hline No & \multicolumn{1}{|c|}{ Syarat Untuk Dijadikan Sampel } \\
\hline 1 & $\begin{array}{l}\text { Minimalmaudah berkunjung ke Malang Dorm } \\
\text { Hostel sebanyak 2(dua) kali. }\end{array}$ \\
\hline 2 & $\begin{array}{l}\text { Bukan orang yang disuruh untuk berkunjung } \\
\text { melainkan merupakan pelanggan Malang Dorm } \\
\text { Hostel. }\end{array}$ \\
\hline
\end{tabular}

Jenis pertanyaan yang digunakan dalam kuesioner penelitian ini adalah berupa pertanyaan tertutup (close ended question). Teknik yang digunakan dalam pengambilan sampel yang dilakukan pada penelitian ini adalah judgement sampling yang diukur berdasarkan 6 skala mulai dari sangat tidak setuju sampai sangat setuju. Pemilihan skala likert 1-6 dipilih untuk mengurangi risiko penyimpangan pengambilan keputusan pribadi dan mempunyai kehandalan yang tinggi dengan menghilangkan skala netral atau neutral dengan model kerangka pemikiran seperti gambar 2:

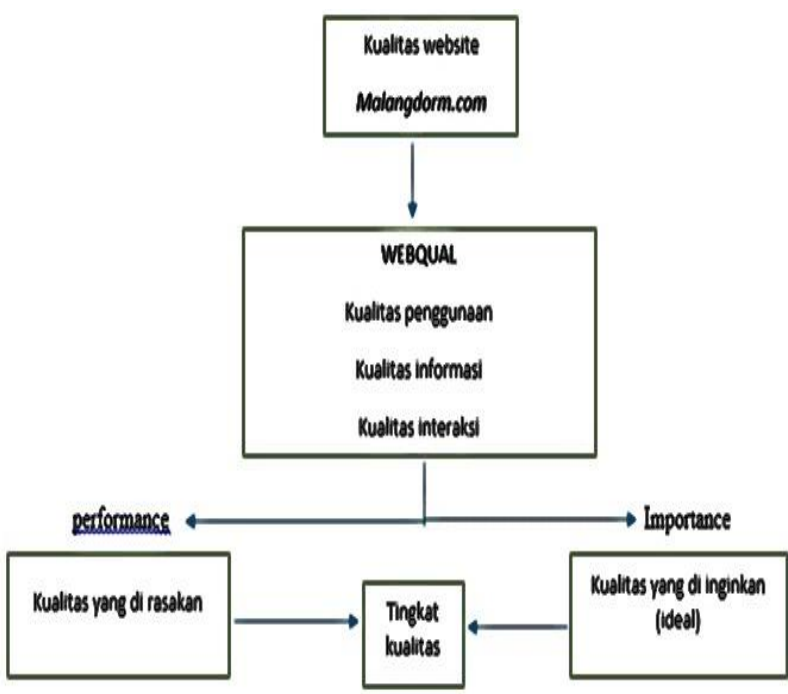

Gambar 2. Kerangka pemikiran

\section{B. Metode Pengumpulan Data}

Teknik pengumpulan data menggunakan instrumen kuesioner yang terdiri dari sejumlah pertanyaan tertulis yang digunakan untuk memperoleh informasi dari responden tentang persepsinya terkait kualitas website. Pengambilan sampel yang digunakan adalah Purposive Sampling dimana pada penelitian ini tidak dilakukan secara konsensus namun secara terfokus yaitu dengan mempertimbangkan kriteriakriteria tertentu yang telah dibuat terhadapobyek yang sesuai dengan tujuan penelitian.

Total populasi dalam penelitian ini yaitu pemilihan pelanggan random (acak) yang pernah menginap dan sedang menginap di Malang Dorm Hostel di tahun2014 - 2016 adalah sebanyak 50 orang. Berdasarkan populasi yang ada maka jumlah minimum sampel yang diambil dapat dihitung dengan menggunakan rumus Slovin sebagai berikut :

$$
n=\frac{M}{1+N e^{2}}
$$

Berdasarkan rumus Slovin diperoleh jumah minimal sampel dengan $5 \%$ error toleranceadalah :

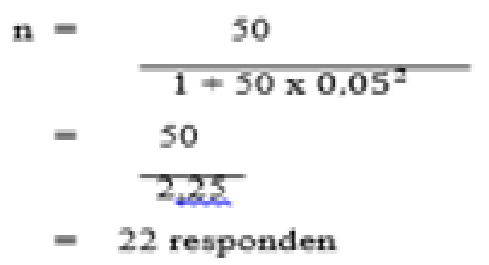

Dengan demikian jumlah sampel dalam penelitian ini adalah 22 responden yakni pelanggan di Malang Dorm 
diHosteltahun 2014 - 2016 dan mengakses situs web Malang Dorm Hostel

\section{Metode Ipa (Importance Performance Analysis)}

Metode Importance Performance Analysis (IPA) pertama kali diperkenalkan oleh Martilla dan James (1977) dengan tujuan untuk mengukur hubungan antara persepsi konsumen dan prioritas peningkatan kualitas produk/jasa yang dikenal pula sebagai quadrant analysis Grafik IPA dibagi menjadi empat buah kuadran berdasarkan hasil pengukuranimportance-performance yang memberikan interpretasi sebagaimana terlihat pada Gambar 3 berikut ini :

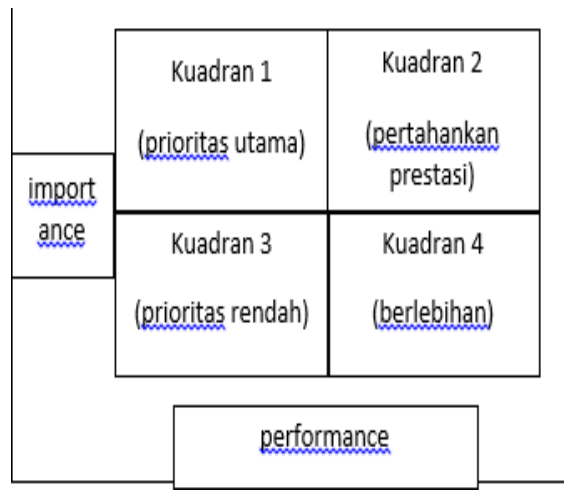

Gambar 3. Pembagian Kuadran Importance Performance Analysis (Sumber: Rangkuti (2003)

Berikut prosedur berkaitan dengan penggunaan metode IPA:

- Penentuan faktor-faktor yang akan dianalisis

- Melakukan survey melalui penyebaran kuesioner

- Menghitung nilai rata-rata tingkat kepentingan (importance) dan tingkat kinerja (performance)

- Membuat grafik IPA

- Melakukan evaluasi terhadap faktor sesuai dengan kuadran masing-masing.

\section{HASIL DAN PEMBAHASAN}

\section{A. Hasil Dan Analisa Data}

Perhitungan dari sistem ini di lakukan antara tahun 20142016 karena di terdapat kesenjangan penuruan pelanggan khusunya di Malang Dorm Hostel. Berdasarkan rata-rata penggunaan website pelanggan memesan kamar dan uji bertanya di lakukan pada tahun 2014 di ketahui sebanyak 41.67\% mengetahui Informasi Malang Dorm Hostel melalui Website resmi, dan pada tahun 2015 sebanyak 38.33\% responden mengetahui dan memesan kamar mengetahui di website resmi Malang Dorm Hostel sisanya sebesar 20\% pada tahun 2016 . Pembobotan data kuesioner menggunakan skala liker (1-6) Berikut ini adalah Tabel 5 yang menggambarkan dari dimensi indikator yang digunakan dalam penelitian ini setelah dilakukan uji validitas dan uji realibilitas beserta dengan nilai performance dan importance masing- masing.

Tabel 5.

Nilai Rata-Rata Pembobotan Indikator

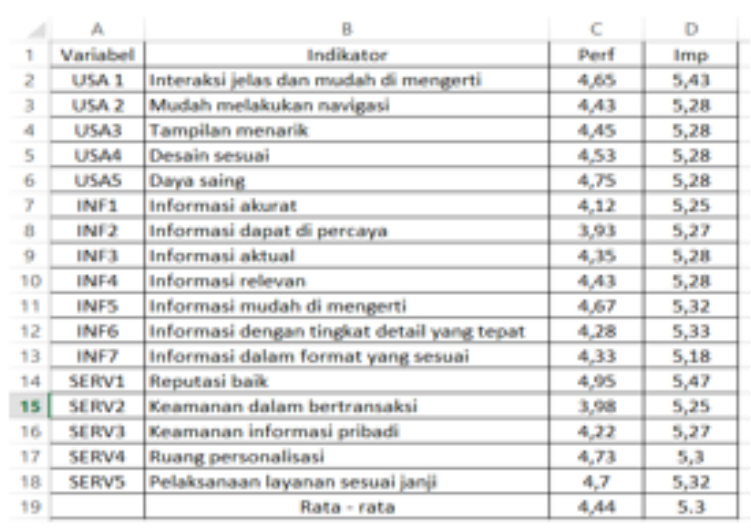

Keterangan : Perform (Performance) dan Imp (Importance)

Analisa kesenjangan (Gap) Proses untuk menentukan nilai kesenjangan (gap) dapat dihitung dari selisih nilai antara nilai kualitas website aktual (Performance) dan kualitas website ideal (Importance).

Qi $($ Gap $)=\operatorname{Perf}(\mathrm{i})-\operatorname{Imp}(\mathrm{i})$

Keterangan :

Qi $($ Gap $)=$ tingkat kesenjangan kualitas

Perf(i) = nilai kualitas yang dirasakan saat ini atauaktual (performance)

$\operatorname{Imp}(i)=$ nilai kualitas ideal atau harapan dan penting untuk dikembangkan (importance)

Tabel 6.

Nilai Kesenjangan Indikator Usability

\begin{tabular}{|c|c|c|c|c|c|}
\hline E13 & 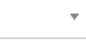 & $\therefore \vee f_{x}$ & & & \\
\hline 2 & A & B & $\mathrm{C}$ & D & $\mathbf{E}$ \\
\hline 1 & Variabel & Indikator & Perf & Imp & $\mathrm{Q}(\mathrm{P}-\mathrm{I}) / \mathrm{Gap}$ \\
\hline 2 & USA 1 & Interaksi jelas dan mudah di mengerti & 4,65 & 5,43 & -0.78 \\
\hline 3 & USA 2 & Mudah melakukan navigasi & 4,43 & 5,28 & -0.85 \\
\hline 4 & USA3 & Tampilan menarik & 4,45 & 5,28 & -0.83 \\
\hline 5 & USA4 & Desain sesuai & 4,53 & 5,28 & -0.75 \\
\hline 6 & USA5 & Daya saing & 4,75 & 5,28 & -0.53 \\
\hline 7 & & Rata - rata & 4,56 & 5,31 & -0.75 \\
\hline
\end{tabular}

Tabel 6 diatas menunjukkan nilai kesenjangan (gap) indikator dalam dimensi usability. Berdasarkan tabel diatas tersebut, dapat dilihat bahwa nilai selisih antara kualitas actual (performance) dan kualitas ideal (importance) dari semua indikator bernilai negatif. Nilai selisih rata-rata gap sebesar -(0.75). Indikator yang memiliki gap terbesar 
adalah pada variabel USA2 yaitu "Mudah melakukan navigasi" dengan selisih gap sebesar -(0.85).

Tabel 7.

Nilai Kesenjangan Indikator Information

\begin{tabular}{|c|c|c|c|c|c|}
\hline \multicolumn{2}{|c|}{ E13 } & $x \vee f_{x}$ & \multirow[b]{2}{*}{ C } & \multirow[b]{2}{*}{$D$} & \multirow[b]{2}{*}{ E } \\
\hline 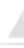 & A & B & & & \\
\hline 1 & Variabel & Indikator & Perf & Imp & $Q(P-1) /$ Gap \\
\hline 2 & INF1 & Informasi akurat & 4.12 & 5.25 & -1.13 \\
\hline 3 & INF2 & Informasi dapat di percaya & 3.93 & 5.27 & $-1,33$ \\
\hline 4 & INF3 & Informasi aktual & 4.35 & 5.28 & $-0,93$ \\
\hline 5 & INF4 & Informasi Relevan & 4.43 & 5.28 & -0.85 \\
\hline 6 & INF5 & Informasi Mudah di mengerti & 4.67 & 5.32 & -0.65 \\
\hline 7 & INF6 & Informasi dengan tingkat detail yang tepat & 4.28 & 5.33 & $-1,05$ \\
\hline 8 & INF7 & Informasi dalam format yang sesuai & 4.33 & 5.18 & -0.85 \\
\hline 9 & & Rata - rata & 4.3 & 5.27 & -0.97 \\
\hline
\end{tabular}

Tabel 7 diatas menunjukkan nilai kesenjangan (gap) indikator dalam dimensi information. Berdasarkan tabel diatas tersebut, dapat dilihat bahwa nilai selisih antara kualitas aktual (performance) dan kualitas ideal (importance) dari semua indikator bernilai negatif. Nilai selisih rata-rata gap sebesar -(0.97). Indikator yang memiliki gap terbesar adalah pada variabel INF2 yaitu "Informasi dapat dipercaya" dengan selisih gap sebesar(1.33).

Tabel 8.

Nilai Kesenjangan Indikator Service Interaction

\begin{tabular}{|c|c|c|c|c|c|}
\hline c & • & $x \vee f_{x}$ & & & \\
\hline & $A$ & B & $C$ & D & $E$ \\
\hline 1 & Variabel & Indikator & Perf & Imp & $Q(P-1) /$ Gap \\
\hline 2 & SERV1 & Reputasi baik & 4.95 & 5.47 & -0.52 \\
\hline 3 & SERV2 & Keamanan dalam bertransaksi & 3.98 & 5.25 & -1.27 \\
\hline 4 & SERV3 & Keamanan informasi pribadi & 4.22 & 5.27 & $-1,05$ \\
\hline 5 & SERVA & Ruang personalisasi & 4.73 & 5.3 & -0.57 \\
\hline 6 & SERV5 & Pelaksanaan layanan sesuai janji & 4.7 & 5.32 & -0.62 \\
\hline & & Rata- rata & 4.52 & 5.32 & -0.8 \\
\hline
\end{tabular}

Tabel 8 diatas menunjukkan nilai kesenjangan (gap) indikator dalam dimensi service interaction. Sama halnya dengan dua dimensi sebelumnya, dimana nilai selisih dari semua indikator dalam dimensi ini bernilai negatif. Nilai selisih rata-rata gap sebesar -(0.80). Indikator yang memiliki gap terbesar adalah pada variabel SERV2 yaitu "Keamanan dalam bertransaksi" dengan selisih gap sebesar -(1.27)
Tabel 9.

Nilai Kesenjangan Semua Indikator dengan Metode WEBQUAL

\begin{tabular}{|l|c|c|c|}
\multicolumn{1}{|c|}{ B } & \multicolumn{2}{c|}{} \\
\multicolumn{1}{|c|}{ Indikator } & C & D & E \\
\hline Usability & Perf & Imp & Q(P-I)/Gap \\
\hline Information & 4.56 & 5.31 & -0.75 \\
\hline Service Interaction & 4.3 & 5.27 & -0.97 \\
\hline Rata - rata & 4.52 & 5.32 & -0.8 \\
\hline
\end{tabular}

Tabel 9 diatas menunjukkan nilai kesenjangan atau gap dari ketiga dimensi WEBQUAL. Berdasarkan tabel diatas, secara keseluruhan, nilai selisih antara kualitas aktual (performance) dan kualitas ideal (importance) memiliki nilai negatif. Nilai selisih rata-rata sebesar -(0.84). Dimensi yang memiliki gap terbesar adalah information dengan selisihsebesar -(0.97). Hasil tersebut menunjukkan nilai negatif atau $\mathrm{Q}<0$ yang berarti bahwa kualitas aktual yang dirasakan saat ini belum dapat memenuhi kualitas ideal yang diinginkan pengguna, maka tingkat kualitas dinyatakan masihburuk.

\section{B. Analisa Diagram Importance PerformanceAnalysis} (IPA)

Hasil dari analisis IPA menunjukan letak masingmasing indikator dalam matrix IPA yang terdiri dari empat kuadran. Proses dalam menentukan kordinat untuk setiap indikator, digunakanlah nilai rata-rata pembobotan indikator dari Tabel 5. Berikut ini Gambar 4 yang menunjukan posisi indikator dalam grafik matrix IPA, dimana masing - masing dimensi digambarkan dengan masing-masing label.

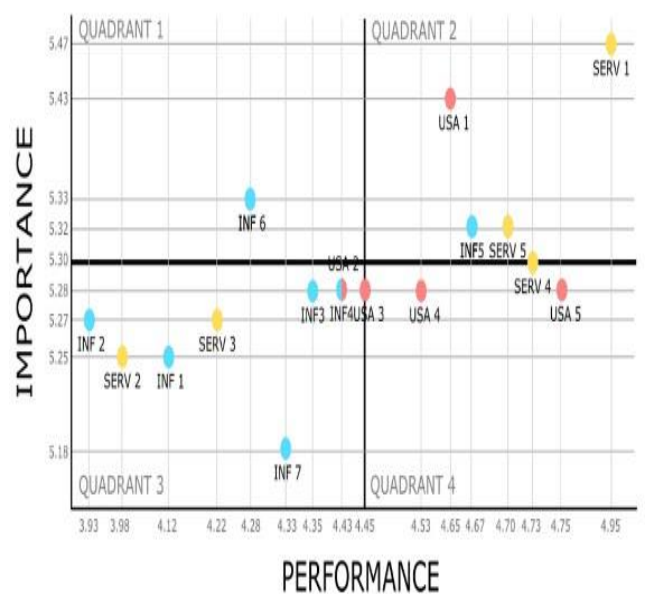

Gambar 4. Diagram Importance-Performance Analysis (IPA) menggunakan aplikasi SPSS 
Berikut ini adalah analisis berdasarkan pembagian kuadran berdasarkan grafik IPA di atas:

- Kuadran I : Indikator INF6 yaitu "Informasi dengan tingkat detail yang tepat" dimana pada kuadran ini indikator belum sesuai dengan harapan pengguna serta memiliki tingkat kepentingan yang tinggi (harapan tinggi), namun tingkat kinerja (aktual) dinilai rendah dan indikator ini diharapkan menjadi prioritas utama dalam pengembangan website Malang Dorm Hostel kedepannya.

- Kuadran II : Indikator USA1 yaitu "Interaksi jelas dan dapat dimengerti" , SERV1 yaitu "Reputasi baik" , SERV5 yaitu "Pelaksanaan layanan sesuai janji", INF5 yaitu "Informasi mudah dimengerti". Pada kudaran ini memiliki tingkat kepentingan (harapan) yang tinggi dan tingkat kinerja (aktual) pun sudah baik. Indikatorindikator pada kuadaran ini dianggap sudah sesuai dengan keinginan pengguna dan harus dipertahankan bagi website Malang Dorm Hostel untuk kedepannya agar menjadi lebih baik.

- Kuadran III : Indikator INF2 yaitu "Informasi dapat dipercaya", SERV2 yaitu "Keamanan dalam bertransaksi", INF1 yaitu "Informasi akurat", SERV3 yaitu "Keamanan informasi pribadi", INF7 yaitu "Informasi dalam format yang sesuai", INF3 yaitu“Informasi aktual", INF4 yaitu "Informasi relevan" dan USA2 yaitu "Mudah melakukan navigasi". Pada kuadran ini memiliki tingkat kepentingan (harapan) yang rendah dan tingkat kinerja (aktual) tidak terlalu dirasakan baik oleh pengguna. Indikator pada kuadran ini dianggap telah sesuai dikembangkan oleh website Malang Dorm Hostel dan dirasa bukan menjadi prioritas utama perbaikan oleh manajemen website Dorm Hostel.

- Kuadran IV : Indikator USA4 yaitu "Desain sesuai" dan USA5 yaitu "Daya Saing". Pada kuadran ini, indikator dinilai memiliki tingkat kepentingan (harapan) yang rendah namun tingkat kinerja (aktual) dari website Malang Dorm Hostel telah dinilai sudah sangat baik oleh pengguna. Indikator pada kuadran ini dinilai telah jauh melampaui harapan pengguna dan dapat sedikit diabaikan oleh manajemen untuk prioritas pengembangan manajemen Dorm Hostel.

- Berpotongan : Indikator SERV4 yaitu "Ruang personalisasi” dimana pada kuadran II dan IV menggambarkan bahwa website Malang Dorm Hostel memiliki tingkat kepentingan (harapan) yang tinggi dan tingkat kinerjanya (performance) sudah baik, serta memiliki tingkat kinerja yang rendah namun kinerja sudah dinyatakan baik oleh pengguna.

Penelitian ini menunjukan perlunya upaya manajemen dari website Malang Dorm Hostel dalam upaya meningkatkan kualitas website agar dapat memenuhi kesesuaian dari para pengguna.

\section{KESIMPULAN DAN SARAN}

Berdasarkan hasil evaluasi kualitas layanan website Malang Dorm Hostel dengan menggunakan metode WEBQUAL dan Importance-Performance Analysis (IPA), maka dapat diambil kesimpulan bahwa kualitas aktual yang dirasakan belum bisa memenuhi kualitas ideal yang diinginkan pengguna website Malang Dorm Hostel terutama dari atribut kualitas yang berhubungan dengan informasi dalam website. Bagi manajemen website Malang Dorm Hostel, hasil penelitian ini dapat dijadikan acuan untuk mengembangkan website yang lebih baik. Pengembangan bisa difokuskan kepada atribut kualitas mengenai informasi terutama dari aspek informasi dengan tingkat detail yang tepat.

Saran untuk penelitian selanjutnya bisa dikembangkan dengan menggabungkan metode webqual 4.0 dan IPA dengan metode lainnya sehingga hasil penelitian tidak hanya fokus pada analisa kuadran IPA saja. Bisa juga diteruskan hingga rekomendasi design interfance baru untuk website Malang Dorm Hostel. Untuk responden kuesioner diharapkan pada penilitian selanjutnya bisa lebih banyak mendapatkan responden dari pihak pemilik resmi penginapan Malang Dorm Hostel.

\section{DAFTAR PUSTAKA}

[1] I. Darimi, "TEKNOLOGI INFORMASI DAN KOMUNIKASI SEBAGAI MEDIA,” vol. 1, pp. 111$121,2017$.

[2] R. A. Kurniawati, A. Kusyanti, and Y. T. Mursityo, "Analisis Pengaruh Kualitas Website Terhadap Kepuasan Pelanggan Mister Aladin Dengan Menggunakan Webqual 4 . 0," vol. 2, no. 3, pp. 11511160, 2018.

[3] I. Budiman et al., "PENERAPAN USABILITY TESTING TERHADAP," vol. 03, no. 02, pp. 182194, 2016.

[4] E. Herrera-viedma, A. G. Lopez-herrera, and C. Porcel, "Evaluating the Information Quality of Web Sites: A Methodology Based on Fuzzy Computing With Words," vol. 57, no. 4, pp. 538-549, 2006.

[5] E. K. Alotaibi and P. A. Lockwood, "Interaction Quality in Service Encounter: Scale Development and Validation," 2011.

[6] P. Metode, W. Terhadap, A. Manik, I. Salamah, and E. 
Susanti, "PENGGUNA WEBSITE POLITEKNIK NEGERI SRIWIJAYA THE IMPACT OF WEBQUAL 4 . 0 METHOD TOWARDS USER," pp. 477-484, 2017.

[7] I. Performance, A. Ipa, P. Situs, B. S. Santoso, and M. F. Anwar, "ANALISIS KUALITAS WEBSITE MENGGUNAKAN METODE WEBQUAL DAN IMPORTANCE - PERFORMANCE ANALYSIS ( IPA ) PADA SITUS KASKUS," no. September, 2015.

[8] R. Kemala, D. Siregar, and R. A. Fitriawan, “ANALISIS KUALITAS WEBSITE RUANGGURU . COM MENGGUNAKAN WEBQUAL 4 . 0 DAN IPA ( IMPORTANCE ANALYSIS ) RUANGGURU . COM WEBSITE QUALITY ANALYSIS USING WEBQUAL 4 . 0 AND IPA ( IMPORTANCE PERFORMANCE ANALYSIS )," vol. 5, no. 1, pp. 1201-1208, 2018.

[9] "http://malangdorm.com.". 
